\title{
Die Cholera,
}

\section{ihre Ursachen, ihre Verbreitung, ihre Abwehr nnd ihre Heilung.}

\section{Vermuthungen}

nicht blos fïr Aerzte geschrieben

von

Dr. Ludolph von Beckedorff.

Berlin.

Verlag von Veit und Comp.

1848. 
